\title{
BWR 照射ステンレス鋼の照射誘起偏析シミュレーション
}

\author{
川岸礼 佳 ${ }^{1}$ 川野昌 平 ${ }^{1}$ 小 畑 稔 ${ }^{2}$ 川原田義幸 1 \\ 1株式会社東芝電力システム社電力・社会システム技術開発センター \\ 2株式会社東芝電力システム社磯子エンジニアリングセンター
}

J. Japan Inst. Metals, Vol. 73, No. 7 (2009), pp. 518-526

(C) 2009 The Japan Institute of Metals

\section{Simulation of Radiation Induced Grain Boundary Segregation in Stainless Steels under Boiling Water Reactor Conditions}

\author{
Ayaka Kawagishi ${ }^{1}$, Shohei Kawano ${ }^{1}$, Minoru Obata $^{2}$ and Yoshiyuki Kawaharada ${ }^{1}$ \\ ${ }^{1}$ Power and Industrial Systems Research and Development Center, Power Systems Company, Toshiba Corporation, \\ Yokohama 235-8523 \\ ${ }^{2}$ Isogo Nuclear Engineering Center, Power Systems Company, Toshiba Corporation, Yokohama 235-8523
}

\begin{abstract}
The radiation induced segregation (RIS) at grain boundary (GB) in neutron irradiated type 316 stainless steel (SS) under boiling water reactor (BWR) condition was simulated by using the $\mathrm{Fe}-\mathrm{Cr}-\mathrm{Ni}-\mathrm{Si}$-Mo system model in which vacancy and interstitial mechanisms were considered for solute migration. The material constants used in the model were fixed to fit the experimental results on RIS at GB. The calculated depth and width of concentration profiles near GB in type 316 SS were comparable to the reported experimental results. The degrees of GB segregation were enhanced at lower neutron flux, and the tendency of flux dependence was similar to experimental results. The theoretical model is applicable to predict the RIS at GB to type 316 SS irradiated in BWR.
\end{abstract}

(Received December 25, 2008; Accepted April 13, 2009)

Keywords: stainless steel, boiling water reactor, neutron irradiation, radiation induced segregation, grain boundary, simulation

\section{1. 緒言}

原子力発電プラントの炉内構造物は, 高温水中で耐食性に すぐれるオーステナイト系ステンレス鋼で主に構成される. オーステナイト系ステンレス鋼が炉心付近で中性子照射を受 けると, 機械的特性や耐食性が次第に変化することが知られ ている.こうした中性子照射に伴う材料劣化事象の一つとし て照射誘起応力腐食割れ (IASCC: Irradiation assisted stress corrosion cracking) があり, 炉内構造物の長期健全性に関わ る重要な課題である. 沸騰水型原子炉 (BWR: Boiling water reactor)においては制御棒シースやハンドル等でIASCC の 発生事例が報告されて打り1), また加圧水型原子炉(PWR: Pressurized water reactor) ではバッフルフォーマボルトの損 傷が報告されている2).このため IASCCの発生メカニズム に基づいてステンレス鋼の照射劣化を予測するシミュレーシ ヨン技術の開発や, 高耐食性ステンレス鋼の開発が, 現在行 われている.

ステンレス鋼のIASCCを促進する要因の一つとして，照 射誘起粒界偏析が挙げられる.すなわちステンレス鋼中の結 晶粒界近傍の原子が中性子照射により移動し, 粒界の $\mathrm{Cr}$ や Mo 量が選択的に減少することにより腐食特性が劣化し, 高 温水中で粒界型応力腐食割れ (IGSCC: Intergranular SCC) が発生すると考えられている ${ }^{3,4)}$. 照射誘起粒界偏析の機構
としては, はじき出しにより生じた空孔と溶質原子との位置 交換に起因する空孔機構と, 格子間原子が溶質原子との複合 体として拡散する格子間原子機構の 2 つの機構があり, こ のような機構論に基づいた反応速度論的シミュレーション手 法がこれまでに提案されている5,6).

ステンレス鋼の主要構成元素である $\mathrm{Fe}-\mathrm{Cr}-\mathrm{Ni} 3$ 元系とし て取り扱うモデルでは, 一般的に空孔機構と格子間原子機構 の 2 つの機構で照射誘起偏析がモデル化されている7,8). た Sakaguchi ら ${ }^{9)}$ は $\mathrm{Fe}-\mathrm{Cr}-\mathrm{Ni} 3$ 元系の偏析に対する $\mathrm{Si}$ や P 等の添加元素の影響を検討するため, $\mathrm{Fe}-\mathrm{Cr}-\mathrm{Ni}-\mathrm{Si} 4$ 元系の モデルを提案している. 具体的には添加元素による点欠陥卜 ラップ効果を点欠陥反応に取り込むもので, 添加元素自体の 偏析は取り扱われていない。ささらに最近 Fukuya ら Sakaguchi らの $\mathrm{Fe}-\mathrm{Cr}-\mathrm{Ni}-\mathrm{Si} 4$ 元系への拡張の考え方を用い て, Fe-Cr-Ni-Si-Mo 5 元系モデルを提案した. この 5 元系 モデルについて, 拡散定数等の主要な物理定数に対する感度 解析を行い, PWR 内で照射された冷間加工 316 ステンレス 鋼の測定データに基づいて実効的な物理定数を設定した結 果, 粒界偏析データを解析により, よく再現できることを示 した.

一方，ステンレス鋼の照射劣化は中性子束に依存すること が知られており11), 評価する照射材の中性子束条件下にお いて照射誘起粒界偏析を精度よく予測できる必要がある。 BWR 炉内構造物の高速中性子束は $10^{15} \mathrm{n} / \mathrm{m}^{2} / \mathrm{s}(E>1 \mathrm{MeV})$ 
のオーダーであり ${ }^{12)}$ ，損傷速度では約 $10^{-10} \mathrm{dpa} / \mathrm{s}$ に相当 し ${ }^{3)}$, PWR 炉心構造物のコアバレルと比べても 1 桁小さい. BWR 炉内で照射されたステンレス鋼の粒界偏析を解析した 例として, $\mathrm{Fe}-\mathrm{Cr}-\mathrm{Ni} 3$ 元系モデルを用いた SUS304 に関す る論文 ${ }^{13)}$ があるが，SUS316 についてはまだ報告されていな w.

そこで本研究では, BWR 炉内で照射されたステンレス鋼 に対する $\mathrm{Fe}-\mathrm{Cr}-\mathrm{Ni}-\mathrm{Si}-\mathrm{Mo} 5$ 元系モデルの適用性を検討す ることを目的とした. BWRの照射条件に拈いて, 粒界偏析 に対する主要な物理定数の感度解析を実施し, 報告されてい る BWR 照射 316 ステンレス鋼の粒界偏析測定データを再 現する実効的な物理定数を設定した.そして，ステンレス鋼 中の粒界偏析に及ぼす照射量や中性子束の影響を解析し, 実 験データと解析結果との比較を行った. また, 粒界偏析に与 える中性子束の影響を検討したので報告する.

\section{2. 計 算 方 法}

\section{1 計算モデル}

金属材料が中性子照射を受けると, 中性子による原子のは じき出しにより空孔と格子間原子が生じる. 生じた空孔や格 子間原子の拡散により, 溶質原子の偏析が生じる. 拡散の具 体的な機構として, 溶質原子と空孔とが位置交換する空孔機 構, 溶質原子と格子間原子の複合体が拡散する格子間原子機 構があり, Fig. 1 に概要を示す.

拡散に関わる空孔, 格子間原子, 溶質原子それぞれの濃度 の時間変化は, 以下の微分方程式で記述される.

$$
\begin{aligned}
& \frac{\partial C_{\mathrm{v}}}{\partial t}=\eta G_{\mathrm{dpa}}-R_{\mathrm{v}-\mathrm{i}} C_{\mathrm{v}} C_{\mathrm{i}}-D_{\mathrm{v}} \sum_{\mathrm{d}}\left(C_{\mathrm{v}}-C_{\mathrm{v}}^{0}\right) S_{\mathrm{v}}^{\mathrm{d}}-\nabla J_{\mathrm{v}} \\
& \frac{\partial C_{\mathrm{i}}}{\partial t}=\eta G_{\mathrm{dpa}}-R_{\mathrm{v}-\mathrm{i}} C_{\mathrm{v}} C_{\mathrm{i}}-D_{\mathrm{i}} C_{\mathrm{i}} \sum_{\mathrm{d}} S_{\mathrm{i}}^{\mathrm{d}}-\nabla J_{\mathrm{i}} \\
& \frac{\partial C_{\mathrm{k}}}{\partial t}=-\nabla J_{\mathrm{i}}
\end{aligned}
$$

ここで, $C_{\mathrm{d}}(\mathrm{d}=\mathrm{i}, \mathrm{v})$ は空孔濃度および格子間原子濃度, $C_{\mathrm{k}}$ $(\mathrm{k}=\mathrm{Fe}, \mathrm{Cr}, \mathrm{Ni}, \mathrm{Si}, \mathrm{Mo})$ は各溶質原子の濃度であり, $J_{\mathrm{v}}, J_{\mathrm{i}}, J_{\mathrm{k}}$



Vacancy- mechanism (inverse-Kirkendall effect)

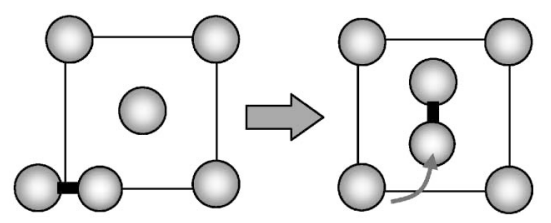

Interstitial- mechanism (dumbbell model)

Fig. 1 The radiation induced segregation (RIS) mechanism in the $\mathrm{Fe}-\mathrm{Cr}-\mathrm{Ni}$-Si-Mo system model.
( $\mathrm{k}=\mathrm{Fe}, \mathrm{Cr}, \mathrm{Ni}, \mathrm{Si}, \mathrm{Mo})$ は空孔，格子間原子，各溶質原子の フラックスである。 $\eta$ は欠陥生成効率, $G_{\mathrm{dpa}}$ は損傷速度 $(\mathrm{dpa} / \mathrm{s}), R_{\mathrm{v}-\mathrm{i}}$ は空孔と格子間原子の再結合速度, $D_{\mathrm{v}}, D_{\mathrm{i}}$ は 空孔抢よ゙格子間原子の拡散定数, $S_{\mathrm{v}}^{\mathrm{d}}, S_{\mathrm{i}}^{\mathrm{d}}$ は空孔および格子 間原子に対する欠陷 $\mathrm{d}$ のシンク強度である. $C_{\mathrm{v}}^{0}$ はシンク近 傍における熱平衡空孔濃度であり, 空孔形成エントロピー $S_{\mathrm{f}}^{\mathrm{v}}$ と空孔形成エンタルピー $E_{\mathrm{f}}^{\mathrm{v}}$ を用いて, 次の式で与えた.

$$
C_{\mathrm{v}}^{0}=\exp \left(\frac{S_{\mathrm{f}}^{\mathrm{v}}}{k}\right) \exp \left(\frac{E_{\mathrm{f}}^{\mathrm{v}}}{k T}\right)
$$

ここでは空孔形成エンタルピー $E_{\mathrm{f}}^{\mathrm{v}}$ は, マトリクス中での值 と同じであると仮定した.

空孔, 格子間原子, 各溶質原子のフラックスは以下の式で 表される.

$$
\begin{aligned}
& J_{\mathrm{v}}=-D_{\mathrm{v}} \nabla C_{\mathrm{v}}-\sum_{\mathrm{k}} C_{\mathrm{v}} d_{\mathrm{k}}^{\mathrm{v}} \nabla C_{\mathrm{k}} \\
& J_{\mathrm{i}}=-D_{\mathrm{i}} \nabla C_{\mathrm{i}}-\sum_{\mathrm{k}} C_{\mathrm{i}} d_{\mathrm{k}}^{\mathrm{i}} \nabla C_{\mathrm{k}} \\
& J_{\mathrm{k}}=-D_{\mathrm{k}} \nabla C_{\mathrm{k}}+C_{\mathrm{k}}\left(d_{\mathrm{k}}^{\mathrm{v}} \nabla C_{\mathrm{v}}-d_{\mathrm{k}}^{\mathrm{i}} \beta_{\mathrm{k}} \nabla C_{\mathrm{i}}\right)
\end{aligned}
$$

ここで $D_{\mathrm{k}}(\mathrm{k}=\mathrm{Fe}, \mathrm{Cr}, \mathrm{Ni}, \mathrm{Si}, \mathrm{Mo})$ は各溶質原子の照射促進拡 散係数, $D_{\mathrm{d}}(\mathrm{d}=\mathrm{i}, \mathrm{v})$ は各点欠陥の拡散係数, $d_{\mathrm{k}}^{\mathrm{v}}, d_{\mathrm{k}}^{\mathrm{i}}$ はそれぞ れ空孔機構および格子間原子機構による各溶質原子の部分拡 散係数， $\beta_{\mathrm{k}}$ は各溶質原子と格子間原子の結合因子である.

空孔の拡散係数 $D_{\mathrm{v}}$ は, 溶質原子の部分拡散係数 $d_{\mathrm{k}}^{\mathrm{v}}$ と濃 度 $C_{\mathrm{k}}$ の積の和で表される. 格子間原子の拡散係数 $D_{\mathrm{i}}$ は, 溶質原子の部分拡散係数, 溶質原子と格子間原子の結合因 子, および溶質濃度の積の和で表される. 以上より, 点欠陥 の拡散係数は以下の式で与えられる.

$$
\begin{aligned}
& D_{\mathrm{v}}=\sum_{\mathrm{k}} d_{\mathrm{k}}^{\mathrm{v}} C_{\mathrm{k}} \\
& D_{\mathrm{i}}=\sum_{\mathrm{k}} d_{\mathrm{k}}^{\mathrm{i}} \beta_{\mathrm{k}} C_{\mathrm{k}}
\end{aligned}
$$

溶質原子の照射促進拡散係数は, 各溶質原子について, 空 孔と格子間原子濃度を用いて次式で表される.

$$
D_{\mathrm{k}}=d_{\mathrm{k}}^{\mathrm{v}} C_{\mathrm{v}}+d_{\mathrm{k}}^{\mathrm{i}} \beta_{\mathrm{k}} C_{\mathrm{i}}
$$

部分拡散係数は次式で与えられる.

$$
d_{\mathrm{k}}^{\mathrm{d}}=\frac{1}{6} v_{\mathrm{k}-\mathrm{d}} \lambda_{\mathrm{d}}^{2} Z_{\mathrm{d}} \exp \left(-\frac{E_{\mathrm{k}-\mathrm{d}}^{\mathrm{m}}}{k T}\right)
$$

ここで， $v_{\mathrm{k}-\mathrm{d}}$ は $\mathrm{k}$ 原子に対する点欠陥 $\mathrm{d}(\mathrm{d}=\mathrm{i}, \mathrm{v})$ の振動数因 子, $E_{\mathrm{k}-\mathrm{d}}^{\mathrm{m}}$ は移動エネルギー, $Z_{\mathrm{d}}$ は配位数, $\lambda_{\mathrm{d}}$ はジャンプ間 距離である. 本研究で対象とする SUS316 ステンレス鋼は $\mathrm{FCC}$ 金属であることから $Z_{\mathrm{v}}=12, Z_{\mathrm{i}}=8, \lambda_{\mathrm{v}}=\lambda_{\mathrm{i}}=a_{0} / \sqrt{2}$ と し，式(11)は以下のようになる.

$$
\begin{aligned}
& d_{\mathrm{k}}^{\mathrm{v}}=v_{\mathrm{v}} \omega_{\mathrm{kv}} a_{0}^{2} \exp \left(-\frac{E_{\mathrm{k}-\mathrm{v}}^{\mathrm{m}}}{k T}\right) \\
& d_{\mathrm{k}}^{\mathrm{i}}=\frac{2}{3} v_{\mathrm{i}} \omega_{\mathrm{ki}} a_{0}^{2} \exp \left(-\frac{E_{\mathrm{k}-\mathrm{v}}^{\mathrm{m}}}{k T}\right)
\end{aligned}
$$

$\omega_{\mathrm{k}-\mathrm{d}}$ は $\mathrm{k}$ 原子に対する各点欠皕の相対ジャンプ率, $v_{\mathrm{d}}(\mathrm{d}=\mathrm{i}$, $\mathrm{v})$ は各点欠陥の振動数因子， $a_{0}$ は格子定数である.このと き各元素の部分拡散係数については，振動数因子 $v_{\mathrm{d}}$ に対する 相対ジャンプ率 $\omega_{\mathrm{k}-\mathrm{d}}$ を元素ごとに変化させた．具体的には $\mathrm{Fe}$ の相対ジャンプ率 $\omega_{\mathrm{Fe}-\mathrm{d}}$ を 1 として各元素の相対的な比 率をそれぞれ設定した。

格子間原子と溶質原子 $\mathrm{k}$ との結合因子は, 次式で表され る. 


$$
\beta_{\mathrm{k}}=\frac{\exp \left(E_{\mathrm{k}-\mathrm{i}}^{\mathrm{b}} / k T\right)}{\sum_{\mathrm{k}} C_{\mathrm{k}} \exp \left(E_{\mathrm{k}-\mathrm{i}}^{\mathrm{b}} / k T\right)}
$$

$E_{\mathrm{k}-\mathrm{i}}^{\mathrm{b}}$ は格子間原子と各溶質原子の結合エネルギーである. 結合因子 $\beta_{\mathrm{k}}$ は，格子間原子の移動に伴って運ばれる溶質原 子のうち $\mathrm{k}$ 原子が占める割合を意味する，各溶質原子に異 なる結合エネルギーを与えることにより，格子間原子機構で の偏析しやすさが区別される．

本モデルにおける点欠陷シンクの取り扱いについて以下に 説明する. BWRに抢いては照射温度が $288^{\circ} \mathrm{C}$ と低く, 点欠 陷集合体として転位ループの形成が主であり，キャビティは 形成されないことが報告されている14). キャビティ発生の 有無は照射温度に依存し, $300^{\circ} \mathrm{C}$ 付近では何も形成されない か，形成されても極めて微細な $\mathrm{He}$ バブルや微細ボイドであ ると考えられる。 また，PWRの計算結果によれば，転位 ループの形成を考慮しても，しない場合と偏析挙動にほとん ぞ影響がないと報告されている10)。そこで本モデルでは点 欠陥シンクとして，照射前に存在するネットワーク転位のみ を考慮した，また，粒界近傍の無欠陥領域は照射初期に消失 するため14), 粒界からの距離によるシンクの変化はないと 仮定した.

本モデルでは, 周期的な結晶粒構造を用いており, 結晶粒 の中心位置に拈いて，以下のように境界条件を与えた。

$$
\begin{array}{ll}
j_{\mathrm{k}}(L, t)=0 & (\mathrm{k}=\mathrm{Fe}, \mathrm{Cr}, \mathrm{Ni}, \mathrm{Si}, \mathrm{Mo}) \\
j_{\mathrm{d}}(L, t)=0 & (\mathrm{~d}=\mathrm{v}, \mathrm{i})
\end{array}
$$

また, 結晶粒界に打いては, フラックスは 0 , 各点欠陥濃度 は熱平衡空孔濃度 $C_{\mathrm{v}}^{\mathrm{eq}}$ および熱平衡格子間原子濃度 $C_{\mathrm{i}}^{\mathrm{eq}}$ とし て，以下のように境界条件を与えた。

$$
\begin{aligned}
& J_{\mathrm{k}}(0, t)=0 \quad(\mathrm{k}=\mathrm{Fe}, \mathrm{Cr}, \mathrm{Ni}, \mathrm{Si}, \mathrm{Mo}) \\
& C_{\mathrm{d}}(0, t)=C_{\mathrm{d}}^{\mathrm{eq}} \quad(\mathrm{d}=\mathrm{v}, \mathrm{i})
\end{aligned}
$$

\subsection{BWR 照射 316 ステンレス鋼の粒界偏析測定データ}

BWR で照射された SUS316 ステンレス鋼の粒界偏析を測 定した研究事例として以下の報告がある.Asano ら ${ }^{15)} は$, 炉内で照射された SUS316 製インコアチューブ (0.005C$0.58 \mathrm{Si}-1.73 \mathrm{Mn}-0.021 \mathrm{P}-0.006 \mathrm{~S}-13.10 \mathrm{Ni}-16.55 \mathrm{Cr}-2.25 \mathrm{Mo}-$ $\mathrm{Fe}$, 中性子照射量 : $4.0,9.2 \times 10^{25} \mathrm{n} / \mathrm{m}^{2}, E>1 \mathrm{MeV}$ ) 加分 析用試験片を採取し, 粒界からの距離が $2.5,5,7.5,10,15$, 20, 25, 30, $50 \mathrm{~nm}$ での 6 元素 $(\mathrm{Fe}, \mathrm{Cr}, \mathrm{Ni}, \mathrm{Si}, \mathrm{Mo}, \mathrm{P})$ の組成を FEG-STEM とEDSにより測定した結果を報告している. Chatani ら ${ }^{16)}$ は, BWR 炉内構造物の SUS316 製トップガイ ド $(0.059 \mathrm{C}-0.83 \mathrm{Si}-1.62 \mathrm{Mn}-0.030 \mathrm{P}-0.006 \mathrm{~S}-11.46 \mathrm{Ni}-$ $17.40 \mathrm{Cr}-2.39 \mathrm{Mo}-\mathrm{Fe}$ ，中性子照射量 : $0.20 \sim 1.3 \times 10^{25} \mathrm{n} / \mathrm{m}^{2}$, $E>1 \mathrm{MeV}$ ) から分析用試験片を採取し, 粒界からの距離 1 , $2,3,4,5,10,20,50 \mathrm{~nm}$ での 6 元素 $(\mathrm{Fe}, \mathrm{Cr}, \mathrm{Ni}, \mathrm{Si}, \mathrm{Mo}, \mathrm{P})$ の 組成を FEG-STEM と EDS により $\phi 2 \mathrm{~nm}$ の電子プローブ 径を用いて測定した。中性子束の範囲は, Asano らのデー

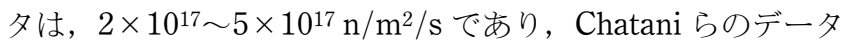
は $5 \times 10^{15} \sim 3 \times 10^{16} \mathrm{n} / \mathrm{m}^{2} / \mathrm{s}$ である. 本研究では，これらの 測定データを用いて以下に示す物理定数の感度解析および計 算条件による計算結果との比較を行うとともに，中性子束の 影響を検討した。
※電界放射走査型透過電子顕微鏡 $(\mathrm{FEG}-\mathrm{STEM})$ とエネル ギー分散型 $\mathrm{X}$ 線分光器 (EDS)

\section{3 感度解析方法}

$\mathrm{Fe}-\mathrm{Cr}-\mathrm{Ni}-\mathrm{Mo}-\mathrm{Si} 5$ 元系モデルを BWR 照射 316 ステンレ 又鋼に適用するにあたり，粒界での溶質原子の偏析量に対す る物理定数の影響を調べ, 感度解析を行った. そして影響の 大きい物理定数に対して，実験データを再現するように設定 した。この際, 実験データの空間分解能に合わせて計算結果 の補正を行う必要がある。粒界組成は FEG-STEM と EDS を用いて電子プローブ径 $2 \mathrm{~nm}$ で測定されており, 測定電子 ビームは, ビーム内で電流密度分布を持つ. そこで, 2 次元 ガウス分布の電流密度を仮定して, 空間分解能の補正を行っ た ${ }^{10)}$.なお，初期偏析の影響は実験データとして報告され ていないため，本解析では考慮していない.

感度解析した各物理定数の検討範囲を Table 1 に示す. 影 響度を調べる物理定数を検討範囲内で変化させ，その他の物 理定数に代表值を入力した. 式(12)の空孔の移動エネル ギー $E_{\mathrm{k}-\mathrm{v}}$ については, 文献 8) 抢よび 10 )の使用值 $1.2 \mathrm{eV}$ および $1.5 \mathrm{eV}$ の範囲内で変化させた. 空孔機構における部 分拡散係数の大小関係を $\mathrm{Ni}<\mathrm{Fe}<\mathrm{Cr}<\mathrm{Mo}<\mathrm{Si}$ と仮定し て10)相対ジャンプ率 $\omega_{\mathrm{k}-\mathrm{v}}$ の代表值を設定し, 大小関係を満 足する範囲で各元素の $\omega_{\mathrm{k}-\mathrm{v}}$ を变化させた，また，格子間原 子機構については, $\mathrm{Si}$ の抑制効果と $\mathrm{Ni}$ の促進効果を考慮し て部分拡散係数の大小関係を $\mathrm{Ni}<\mathrm{Fe}=\mathrm{Cr}=\mathrm{Mo}<\mathrm{Si}$ と仮定 し10)，式(13)の相対ジャンプ率 $\omega_{\mathrm{k}-\mathrm{i}}$ を設定した. Table 1 に示した式(13)の格子間原子の移動エネルギー $E_{\mathrm{k}-\mathrm{i}}^{\mathrm{m}}$ の設定 值 $1.1 \mathrm{eV}$ は，例えば，報告されている $\mathrm{Ni}$ の自己拡散の移動 エネルギー $0.15 \mathrm{eV}^{17)}$ と比べて大きい. 文献 17)の值は,

Fig. 1 に示した混合ダンベル移動機構において単純な移動に 要するエネルギーであるが，格子間原子はダンベル状態で籠 鳥運動や回転運動を起こして移動する。 なた，実用鋼の C, $\mathrm{N}$ 等は格子間原子をトラップして偏析を抑制することが知

\begin{tabular}{|c|c|c|}
\hline Parameter & $\begin{array}{l}\text { Standard } \\
\text { value }\end{array}$ & $\begin{array}{l}\text { Used in } \\
\text { sensitivity } \\
\text { analysis }\end{array}$ \\
\hline Migration energy of Vacancy $E_{\mathrm{k}-\mathrm{v}}^{\mathrm{m}}(\mathrm{eV})$ & 1.5 & $1.3,1.4,1.5$ \\
\hline $\begin{array}{l}\text { Relative jump frequency of } \mathrm{Cr} \text { via vacancy } \\
\omega_{\mathrm{Cr}-\mathrm{v}}\end{array}$ & 1.2 & $1.1,1.2,1.3$ \\
\hline $\begin{array}{l}\text { Relative jump frequency of } \mathrm{Ni} \text { via vacancy } \\
\omega_{\mathrm{Ni}-\mathrm{v}}\end{array}$ & 0.5 & $0.4,0.5,0.6$ \\
\hline $\begin{array}{l}\text { Relative jump frequency of Si via vacancy } \\
\omega_{\mathrm{Si}-\mathrm{v}}\end{array}$ & 3 & $3,5,7$ \\
\hline $\begin{array}{l}\text { Relative jump frequency of Mo via vacancy } \\
\omega_{\mathrm{Mo}-\mathrm{v}}\end{array}$ & 2 & $2,4,6$ \\
\hline Migration energy of interstitial $E_{\mathrm{k}-\mathrm{i}}^{\mathrm{m}}(\mathrm{eV})$ & 1.1 & $0.7,0.9$ \\
\hline $\begin{array}{l}\text { Relative jump frequency of Ni via interstitial } \\
\omega_{\mathrm{Ni}-\mathrm{i}}\end{array}$ & 1.4 & $1.2,1.4,1.6$ \\
\hline $\begin{array}{l}\text { Relative jump frequency of Si via interstitial } \\
\omega_{\mathrm{Si}-\mathrm{i}}\end{array}$ & 0.5 & $0.3,0.5,0.7$ \\
\hline $\begin{array}{l}\text { Binding energy between } \mathrm{Ni} \text { and interstitial } \\
E_{\mathrm{Ni}-\mathrm{i}}^{\mathrm{b}}(\mathrm{eV})\end{array}$ & 0 & $0,0.01,0.02$ \\
\hline $\begin{array}{l}\text { Binding energy between } \mathrm{Si} \text { and interstitial } \\
E_{\mathrm{Si}-\mathrm{i}}^{\mathrm{b}}(\mathrm{eV})\end{array}$ & 0.2 & $0.15,0.2,0.25$ \\
\hline
\end{tabular}
られている18).PWR 照射材の計算10)では，これらの籠鳥運 動や回転運動, トラップ効果を考慮して $E_{\mathrm{k}-\mathrm{i}}$ に $1.1 \mathrm{eV}$ が設 定されており, 本研究の解析においても同様の考えに基づい

Table 1 Parameters used in sensitivity analysis. 
て $E_{\mathrm{k}-\mathrm{i}}^{\mathrm{m}}$ を設定した. 式(14)の結合エネルギー $E_{\mathrm{k}-\mathrm{i}}$ はアン ダーサイズ原子 $\mathrm{Ni}$ と $\mathrm{Si}$ について影響度を評価し， $0 \sim 0.02$ および $0.15 \sim 0.25$ の範囲で変化させた ${ }^{10)}$.

\section{4 計算条件}

感度解析で最適化した物理定数を使用し, 実験データでの
照射条件にて $\mathrm{Fe}, \mathrm{Cr}, \mathrm{Ni}, \mathrm{Si}, \mathrm{Mo}$ 各溶質原子の粒界偏析量を 計算し, 欠乏幅と中性子束依存性を調査した。解析に抢ける 照射量および中性子束範囲はそれぞれ $0.2 \sim 9.2 \times 10^{25} \mathrm{n} / \mathrm{m}^{2}$, $5 \times 10^{15} \sim 3 \times 10^{16} \mathrm{n} / \mathrm{m}^{2} / \mathrm{s}$ とした. なお, 計算に使用する損 傷速度は, 中性子束から $1 \mathrm{dpa}=7 \times 10^{24} \mathrm{n} / \mathrm{m}^{2} / \mathrm{s}(E>1$ $\mathrm{MeV})$ の関係3)を用いて求めた。



Migration energy of vacancy/ $\epsilon$

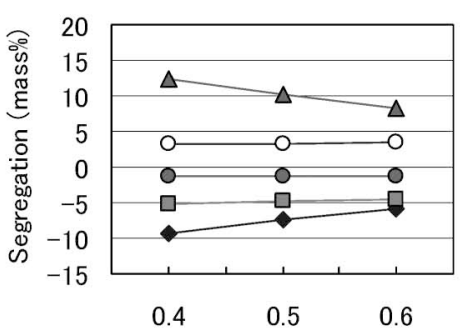

Relative jump frequency of $\mathrm{Ni}$ vi vacancy

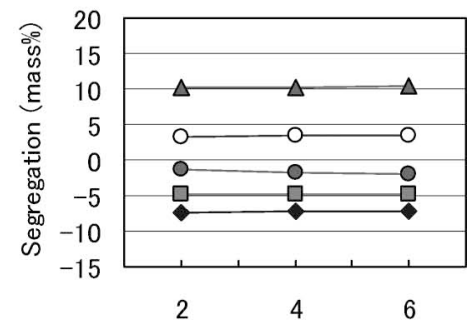

Relative jump frequency of Mo via vacancy

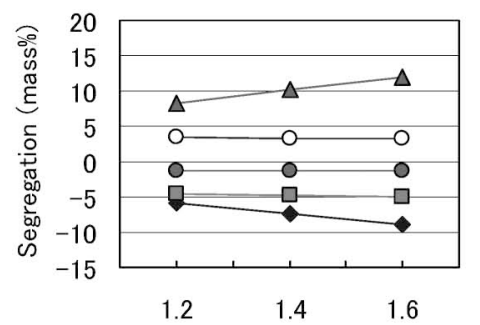

Relative jump frequency of $\mathrm{Ni}$ via interstitial

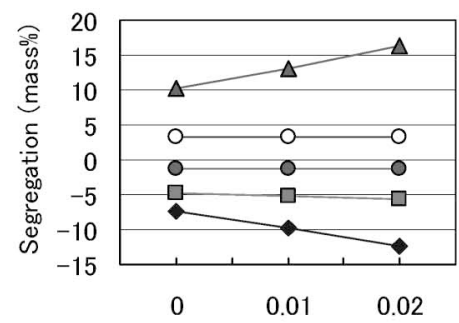

Binding energy of $\mathrm{Ni}$ and interstitial/eV

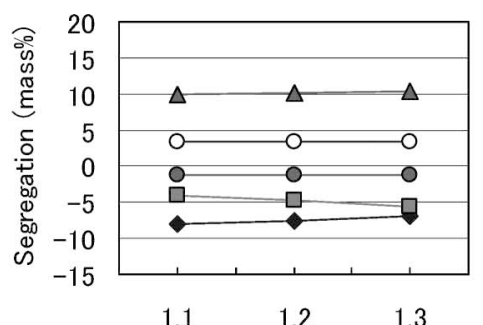

Relative jump frequency of $\mathrm{Cr}$ via vacancy

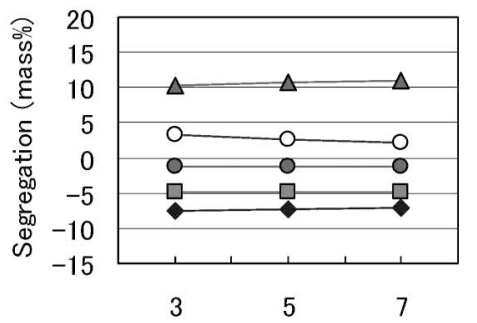

Relative jump frequency of $\mathrm{Si}$ via vacancy

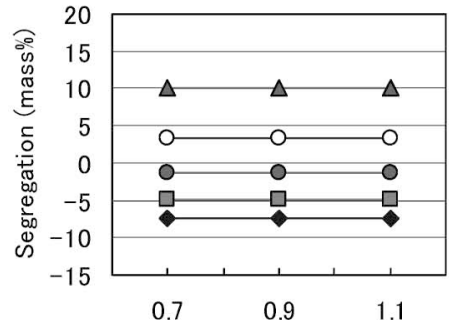

Migration energy of interstitial/eV

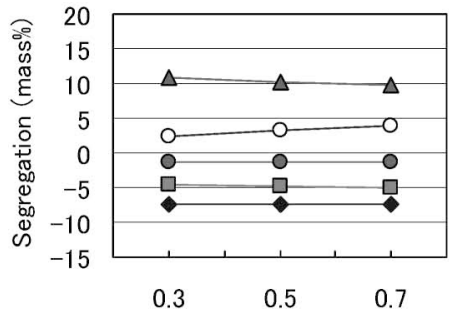

Relative jump frequency of Si via interstitial

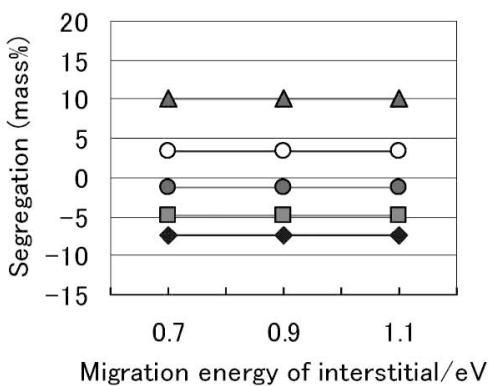

Fig. 2 Calculated results of radiation induced segregation at grain boundary as functions of variable parameters; neutron fluence: $9.2 \times 10^{25} \mathrm{n} / \mathrm{m}^{2}$, neutron flux: $5.4 \times 10^{17} \mathrm{n} / \mathrm{m}^{2} / \mathrm{s}$, temperature: $288^{\circ} \mathrm{C}$. 
照射温度は BWR 炉内で想定される $288^{\circ} \mathrm{C}$ とし, 対象材 料は 316 ステンレス鋼とした. 実験データのステンレス鋼 は固溶化熱処理されているため, 初期ネットワーク転位密度 を $1 \times 10^{10} \mathrm{n} / \mathrm{m}^{2}$ と設定した.

\section{3. 結果および考察}

\section{1 感度解析と物理定数の決定}

溶質原子の偏析量に対する物理定数の影響度を Fig. 2 に 示す。これは, 照射量 $9.2 \times 10^{25} \mathrm{n} / \mathrm{m}^{2}$, 中性子束 $5.4 \times 10^{17}$ $\mathrm{n} / \mathrm{m}^{2} / \mathrm{s}$, 温度 $288^{\circ} \mathrm{C}$ の条件である. 粒界偏析量に対して大 きく影響を与える物理定数として, 空孔移動エネルギー, $\mathrm{Ni}$ と空孔のジャンプ頻度, $\mathrm{Ni}$ と格子間原子のジャンプ頻度, $\mathrm{Ni}$ と格子間原子の結合エネルギー, Si と格子間原子のジャ ンプ頻度，Si と格子間原子の結合エネルギーが粒界偏析に 対して影響が大きい。 また, 溶質原子の中では特に $\mathrm{Ni}$ が物 性值変化の影響を受けやすい.

実験データに基づいて決定した物理定数の值を，PWR 照 射材に基づいて最適化された値 ${ }^{10)}$ と比較して Table 2 に示 す。これらの值は PWR 照射材で最適化された值とほぼ同等 であった。

Fig. 3 に, 粒界での溶質原子 $\mathrm{Fe}, \mathrm{Cr}, \mathrm{Ni}, \mathrm{Si}, \mathrm{Mo}$ の偏析量 について，実験データ 15,16) と $\mathrm{Fe}-\mathrm{Cr}-\mathrm{Ni}-\mathrm{Si}-\mathrm{Mo} 5$ 元系モデル で得られた計算結果との関係を示す.いずれの溶質原子もほ ぼ $1: 1$ の関係を示し, $\mathrm{Fe}-\mathrm{Cr}-\mathrm{Ni}-\mathrm{Si}-\mathrm{Mo} 5$ 元系モデルによ る計算結果は BWR 照射材の実験結果を良く再現した。した がって PWR に比べて中性子束が小さい BWR 照射材に対し ても本モデルが適用可能であるといえる.

Fig. 4 に, 粒界近傍に抢ける溶質原子 $\mathrm{Cr}, \mathrm{Ni}, \mathrm{Mo}$ の濃度 変化分布の計算結果を実験データと比較して示す。照射量は $2.0 \times 10^{24}, 5.4 \times 10^{24}$ および $1.3 \times 10^{25} \mathrm{n} / \mathrm{m}^{2}$, 照射温度 $288^{\circ} \mathrm{C}$ である. 各元素の粒界偏析量の計算結果は, 照射量とともに 大きくなる傾向を示し, $\mathrm{Cr}$ と Mo は減少し Ni は増加する. 感度解析で設定した物理定数を用いているため, 照射に伴う

Table 2 Parameters used in calculation.

\begin{tabular}{|c|c|c|}
\hline Parameter & $\begin{array}{l}\text { Present } \\
\text { study }\end{array}$ & Fukuya ${ }^{10)}$ \\
\hline Migration energy of Vacancy $E_{\mathrm{k}-\mathrm{v}}^{\mathrm{m}}(\mathrm{eV})$ & 1.5 & 1.5 \\
\hline Relative jump frequency of vacancy $v_{\mathrm{v}}(/ \mathrm{s})$ & $1.5 \times 10^{13}$ & $1.5 \times 10^{13}$ \\
\hline Relative jump frequency of $\mathrm{Fe}$ via vacancy $\omega_{\mathrm{Fe}-\mathrm{v}}$ & 1 & 1 \\
\hline Relative jump frequency of $\mathrm{Cr}$ via vacancy $\omega_{\mathrm{Cr}-\mathrm{v}}$ & 1.2 & 1.1 \\
\hline Relative jump frequency of $\mathrm{Ni}$ via vacancy $\omega_{\mathrm{Ni}-\mathrm{v}}$ & 0.6 & 0.4 \\
\hline Relative jump frequency of Si via vacancy $\omega_{\mathrm{Si}-\mathrm{v}}$ & 3 & 3 \\
\hline Relative jump frequency of Mo via vacancy $\omega_{\mathrm{Mo}-\mathrm{v}}$ & 2 & 1.5 \\
\hline Migration energy of interstitial $E_{\mathrm{k}-\mathrm{i}}^{\mathrm{m}}(\mathrm{eV})$ & 1.1 & 1.1 \\
\hline Relative jump frequency of interstitial $v_{\mathrm{i}}(/ \mathrm{s})$ & $1.5 \times 10^{12}$ & $1.5 \times 10^{12}$ \\
\hline $\begin{array}{l}\text { Relative jump frequency of } \mathrm{Fe} \text { via interstitial } \\
\omega_{\mathrm{Fe}-\mathrm{i}}\end{array}$ & 1 & 1 \\
\hline Relative jump frequency of $\mathrm{Cr}$ via interstitial $\omega_{\mathrm{Cr}-\mathrm{i}}$ & 1 & 1 \\
\hline Relative jump frequency of $\mathrm{Ni}$ via interstitial $\omega_{\mathrm{Ni}-\mathrm{i}}$ & 1.4 & 1.3 \\
\hline Relative jump frequency of $\mathrm{Si}$ via interstitial $\omega_{\mathrm{Si}-\mathrm{i}}$ & 0.5 & 0.5 \\
\hline $\begin{array}{l}\text { Relative jump frequency of Mo via interstitial } \\
\omega_{M 0-i}\end{array}$ & 1.1 & 1.1 \\
\hline $\begin{array}{l}\text { Binding energy between } \mathrm{Ni} \text { and interstitial } E_{\mathrm{Ni}-\mathrm{i}}^{\mathrm{b}} \\
(\mathrm{eV})\end{array}$ & 0 & 0 \\
\hline$\underset{(\mathrm{eV})}{\operatorname{Binding}}$ energy between $\mathrm{Si}$ and interstitial $E_{\mathrm{Ni}-\mathrm{i}}^{\mathrm{b}}$ & 0.15 & 0.2 \\
\hline Defect production efficiency $\eta$ & 0.03 & 0.03 \\
\hline
\end{tabular}

偏析量の解析值は, 実験データとよく一致している。また, 粒界偏析が生じている Cr および Mo の欠乏幅は, 照射量 $1.3 \times 10^{25} \mathrm{n} / \mathrm{m}^{2}$ に打いて約 $\pm 6 \mathrm{~nm}$ であり, 粒界偏析の欠乏 幅も解析が測定結果をよく再現することが確認された.

Fig. 5 に, 中性子束 $3 \times 10^{15}, 3 \times 10^{16}$ 抢よび $3 \times 10^{17} \mathrm{n} /$ $\mathrm{m}^{2} / \mathrm{s}$, 照射温度 $288^{\circ} \mathrm{C}$ に抢ける $\mathrm{Cr}, \mathrm{Ni}, \mathrm{Mo}, \mathrm{Si}$ の粒界偏析量 と照射量との関係を, 実験データ15,16) とともに示す。実験 データの中性子束は, $5 \times 10^{15} \sim 5 \times 10^{17} \mathrm{n} / \mathrm{m}^{2} / \mathrm{s}^{15,16)}$ の範囲 である. 各中性子束において, 照射量が高くなるほど偏析が 促進される計算結果が与えられ, 中性子束の影響に関して も, 本解析は再現性がよいことが確認された. Moの実験 データのうち照射量 $5.4 \times 10^{24} \mathrm{n} / \mathrm{m}^{2}$ で逆偏析が認められる が，これは初期偏析の影響と考えられる。

\section{2 中性子束の影響}

Fig. 6 に, 照射量 $1 \times 10^{25} \mathrm{n} / \mathrm{m}^{2}$, 照射温度 $288^{\circ} \mathrm{C}$ におけ る, $\mathrm{Fe}, \mathrm{Cr}, \mathrm{Ni}, \mathrm{Si}, \mathrm{Mo}$ の粒界偏析量と中性子束の関係を示 す. 中性子束が低いほど粒界偏析が促進される傾向であり, $\mathrm{Cr}, \mathrm{Mo}$ は欠乏し Ni, Si は濃縮する.ここで中性子束 $\phi$ と偏 析量 $\Delta C$ の関係について, $\Delta C=a \times(\phi) n$ 型の $n$ 乗式で整理を 試みた. $a$ と $n$ は定数である. $\mathrm{Fe}, \mathrm{Cr}, \mathrm{Ni}, \mathrm{Si}, \mathrm{Mo}$ の偏析量 は, 中性子束に対してそれぞれ， $n=1 / 5,1 / 6,-1 / 5,-1 / 5$, $1 / 10$ 乗に比例する結果となった. $n$ 值に関する検討は従来 報告されていないが，粒界偏析に及ぼす中性子束の影響につ いては実験や解析による検討が行われている. Watanabe $ら^{8)}$ は $\mathrm{Fe}-\mathrm{Cr}-\mathrm{Ni} 3$ 元系モデルを用いて $\mathrm{Fe}-18 \mathrm{Cr}-12 \mathrm{Ni}$ (at\%) 合金の粒界偏析に及ぼす中性子束の影響を解析した結果, 照 射温度 $300^{\circ} \mathrm{C}$ では中性子束の増加とともに粒界偏析が抑制 される解析結果が得られ, その原因として照射欠陥の再結合 が高中性子束側で促進される効果を指摘した. Watanabe ら

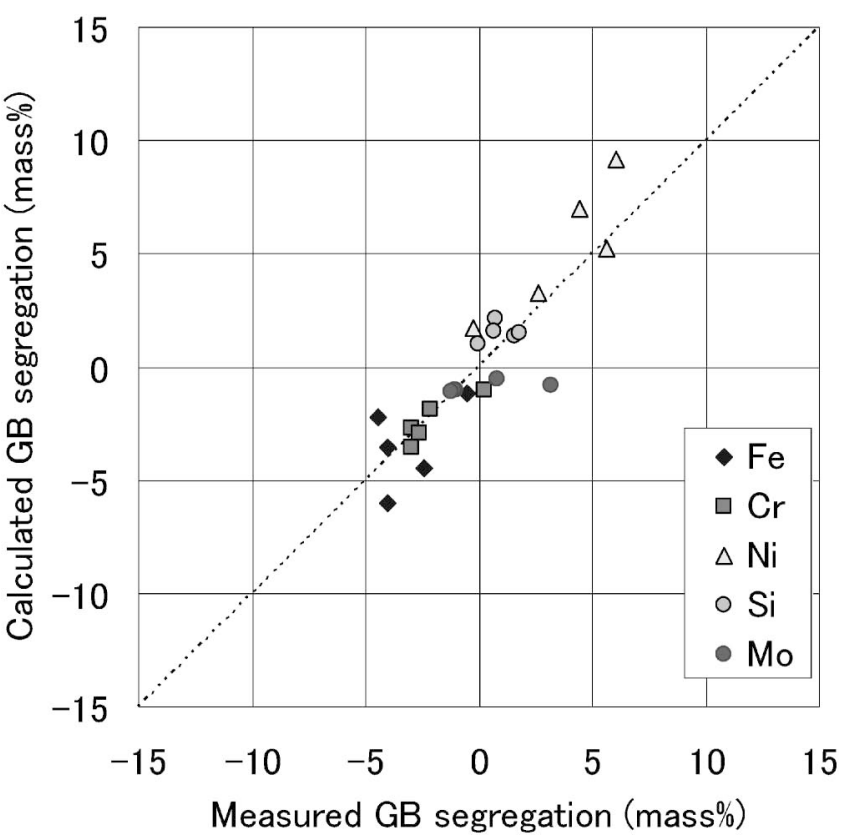

Fig. 3 Comparison of calculated results and experimental data $^{15,16)}$ of grain boundary segregation in type 316 stainless steel. 
(1)

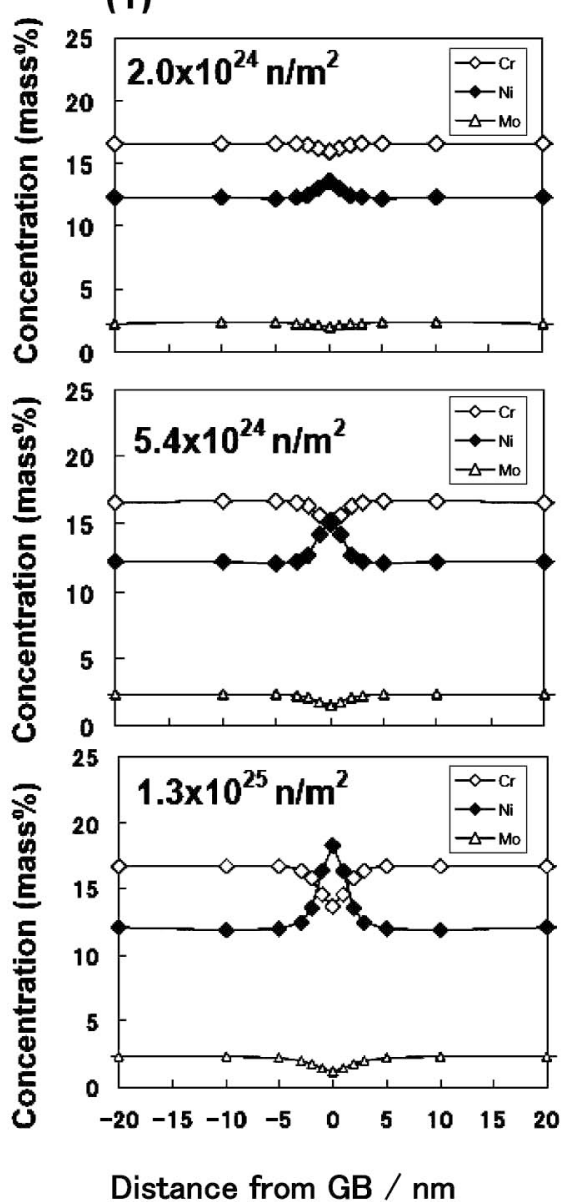

(2)
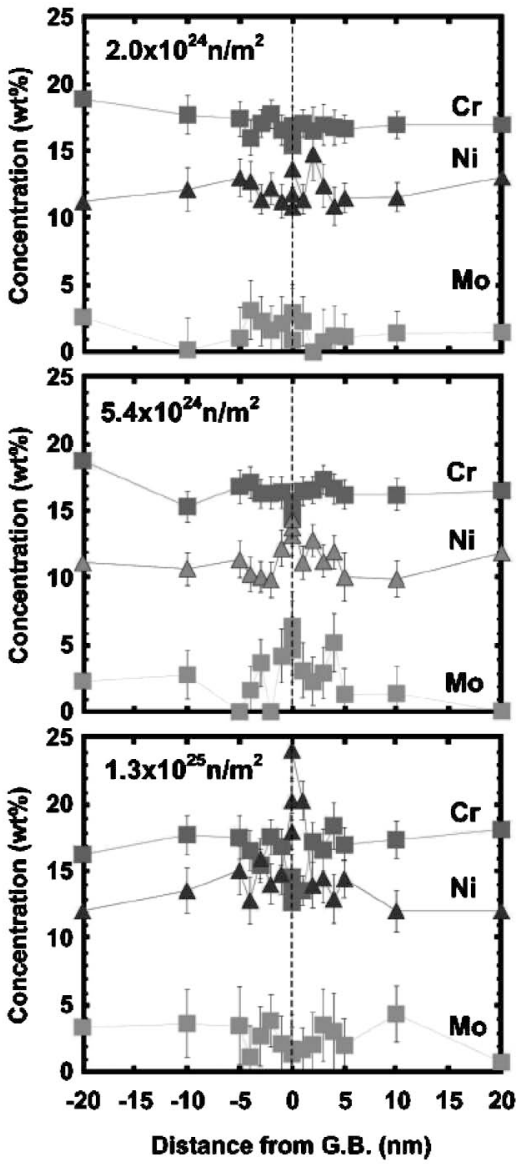

Fig. 4 Comparison of (1) calculated results and (2) experimental data ${ }^{15)}$ of concentration profiles of alloying elements near grain boundary in type 316 stainless steels after boiling water reactor irradiation.

の解析結果を前述の $n$ 乗式で整理すると, 照射温度 $300^{\circ} \mathrm{C}$, 照射量 $3 \mathrm{dpa}$ ，損傷速度が $10^{-8} \sim 10^{-7} \mathrm{dpa} / \mathrm{s}$ の範囲では, $\mathrm{Cr}$ と $\mathrm{Ni}$ の $n$ 值はそれぞれ $1 / 3,-1 / 5$ となっている。 また Allen ら ${ }^{19)}$ は高速炉 EBR-II で照射されたステンレス鋼部材 について，損傷速度の粒界偏析への影響を実験データに基づ いて検討した。例えば照射温度 $279^{\circ} \mathrm{C}$ ，照射量 $10 \sim 19$ $\mathrm{dpa}$ ，損傷速度が $2 \times 10^{-8} \sim 6.6 \times 10^{-8} \mathrm{dpa} / \mathrm{s}$ のとき，304 ス テンレス鋼中の $\mathrm{Cr}$ および $\mathrm{Ni}$ の粒界偏析は, 損傷速度低で 大きいと報告している. この条件での $\mathrm{Cr}, \mathrm{Ni}$ の $n$ 值は， $n=$ 1/4, - 2/5 となっている. Watanabe らの結果は, $5 \times 10^{-4}$ $\mathrm{dpa} / \mathrm{s}$ の高い損傷速度のデータにあわせたモデル予測である こと, Allen らのデータは狭い範囲の中性子束のデータであ ることを考慮すると, 本検討の BWR 相当の中性子束範囲 （損傷速度では $10^{-10} \sim 10^{-8} \mathrm{dpa} / \mathrm{s}$ ) で照射されたステンレス 鋼の $\mathrm{Ni}$ や $\mathrm{Cr}$ で予想される，nの絶対值が $1 / 6 \sim 1 / 5$ 乗の依 存性は定性的に妥当であると考えられる.

粒界偏析量に及ぼす中性子束の影響を以下に考察する. Fig. 7 に照射量 $1 \times 10^{25} \mathrm{n} / \mathrm{m}^{2}$, 照射温度 $288^{\circ} \mathrm{C}$, 中性子束 3 $\times 10^{15} \sim 3 \times 10^{17} \mathrm{n} / \mathrm{m}^{2} / \mathrm{s}$ の条件での粒界付近における，格子 間原子濃度と空孔濃度の中性子束依存性を示す。縦軸の単位 は原子分率である. 中性子束が大きいほど, 粒界近傍の空孔 と格子間原子の平衡濃度は高くなることがわかる.

粒界近傍での点欠陥の反応を検討するため, 粒界近傍の 5 $\mathrm{nm}$ の位置における, 式(1)および式 (2)で表される空孔濃度 および格子間原子濃度の時間変化に対する右辺の各項の寄与 の大きさを, 中性子束をパラメータとして Fig. 8 に示す. ここで, 右辺の第 1 項は中性子照射による欠陥の生成 (Production), 第 2 項は欠陥の再結合による消滅 (Recombination), 第 3 項はネットワーク転位をシンクとする欠陥の 消滅 (Sink), 第 4 項は各欠陥の勾配による流出 (Flow)を表 している. 各寄与の大小の比較を容易にするため, Fig. 8 の 縦軸では絶対值で示した．いずれの欠陥においても，中性子 束が増加するに従い各項の寄与が増加している. Fig. 8 は, 今回検討した溶体化材の低中性子束の BWR 照射では, 空 孔，格子間原子ともに，再結合とシンクに吸収されて消失す る割合は小さく, 生成した点欠陥の大部分は濃度勾配に従う 粒界方向への流出により失われていることを示している.

Fig. 7 では, 低中性子束ほど平衡点欠陥濃度が低いことが示 されているので, 低中性子束で生成した点欠陥は, 高中性子 束の場合よりも流出する点欠陥が多いことを示している. 照 射誘起偏析は濃度勾配により生ずる点欠陥の流れで生ずるた め, Fig. 6 に示されたように, 粒界方向への流れの大きい低 中性子束の方が偏析は進行しやすいこととなると考えられ る. なお, Fig. 8 では中性子束の増加による変化は再結合が 他の項よりも大きい。一般に, 損傷速度が高くなると再結合 の割合が大きくなり, 点欠陥の平衡濃度が低くなるため偏析 


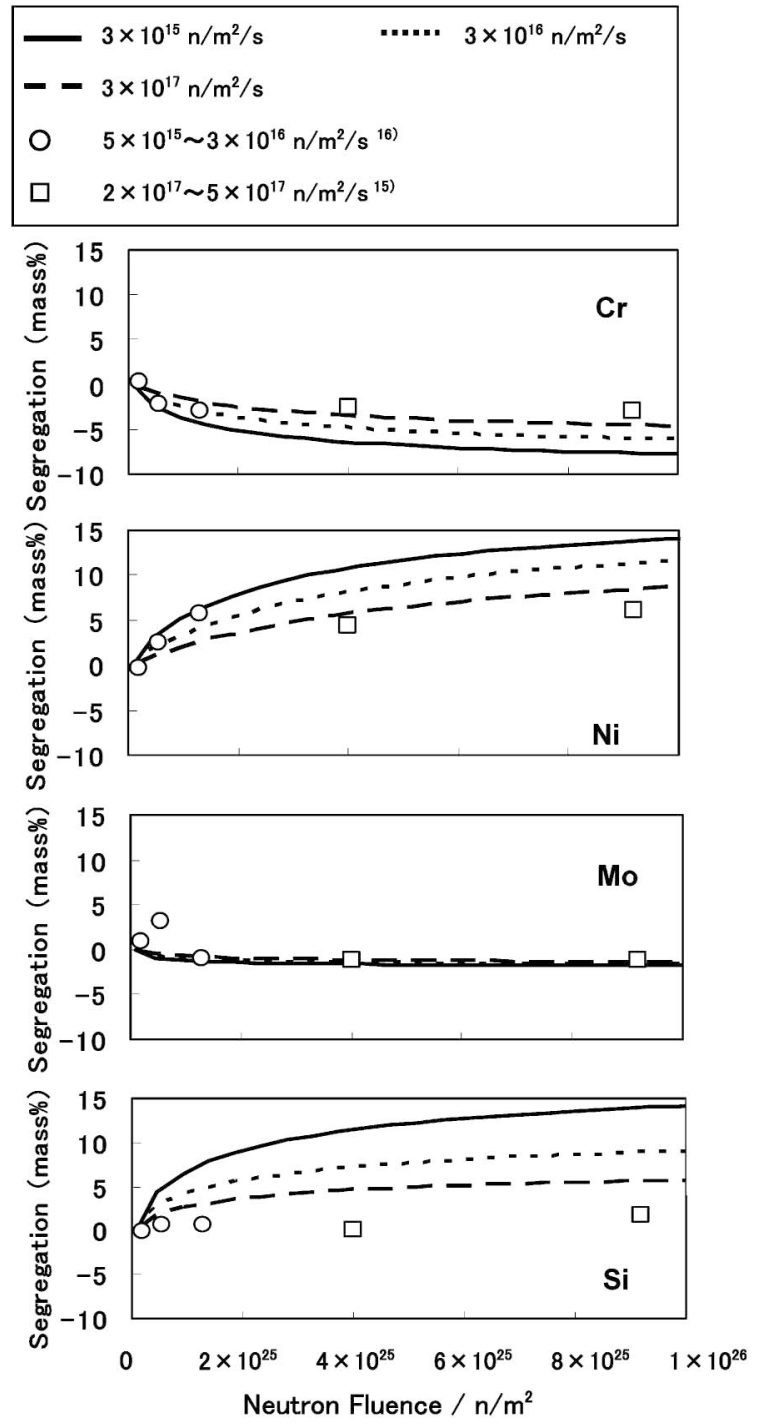

Fig. 5 Comparison of the calculated grain boundary segregation with results of experimental data ${ }^{15,16)}$ as function of neutron fluence for different neutron flux in type 316 stainless steel.
が抑制されると考えられる. Fig. 8 の再結合の傾向を外挿す ると，再結合の割合が大きくなり生成項に近くなるのは，今 回検討した BWRのような低中性子束領域よりも 2 桁以上 高い中性子束と考えられる。そのような場合は損傷速度で $10^{-5} \mathrm{dpa} / \mathrm{s}$ 以上に対応し，イオン照射等で得られる領域で ある。低中性子束領域で，中性子束が低いほど粒界偏析が大 きくなる傾向は，再結合による平衡点欠陥濃度の減少ではな く，点欠陥が効率よく粒界に流れることにより生ずるものと 考えられる．照射誘起偏析に及ぼす中性子束あるいは損傷速 度の影響のメカニズムは，中性子束あるいは損傷速度の範囲 に依存し，また，シンク強度にも依存することが予想され る. 軽水炉のような低中性子束領域で中性子束等の影響を確 かめられるデータは非常に少なく今後のデータの蓄積が待た れるが，本研究ではモデルの適用により中性子束依存性が確

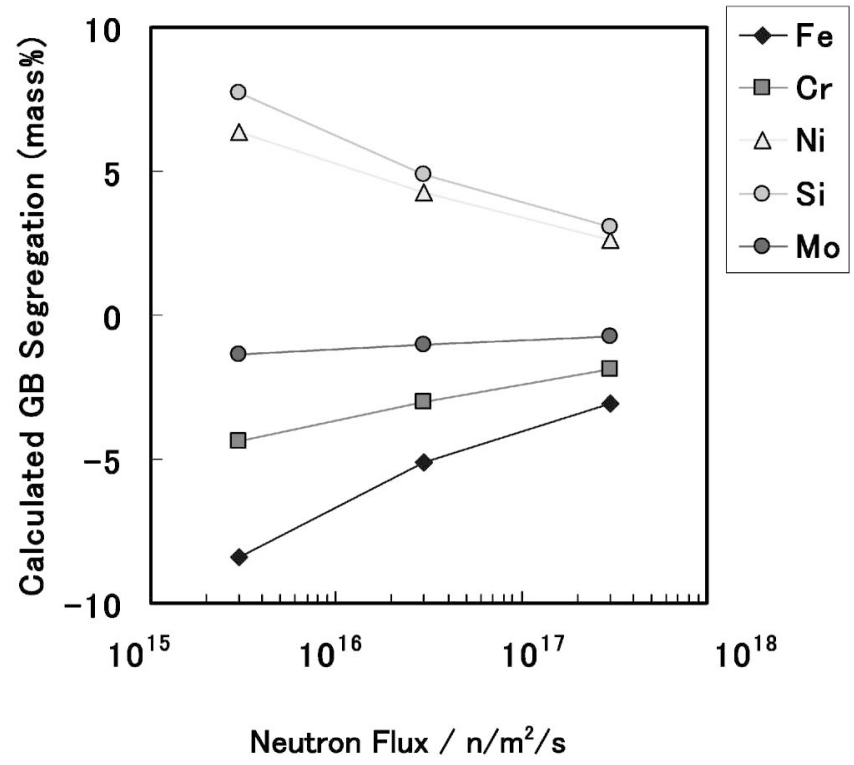

Fig. 6 Neutron flux dependence of calculated grain boundary segregation in type 316 stainless steel.

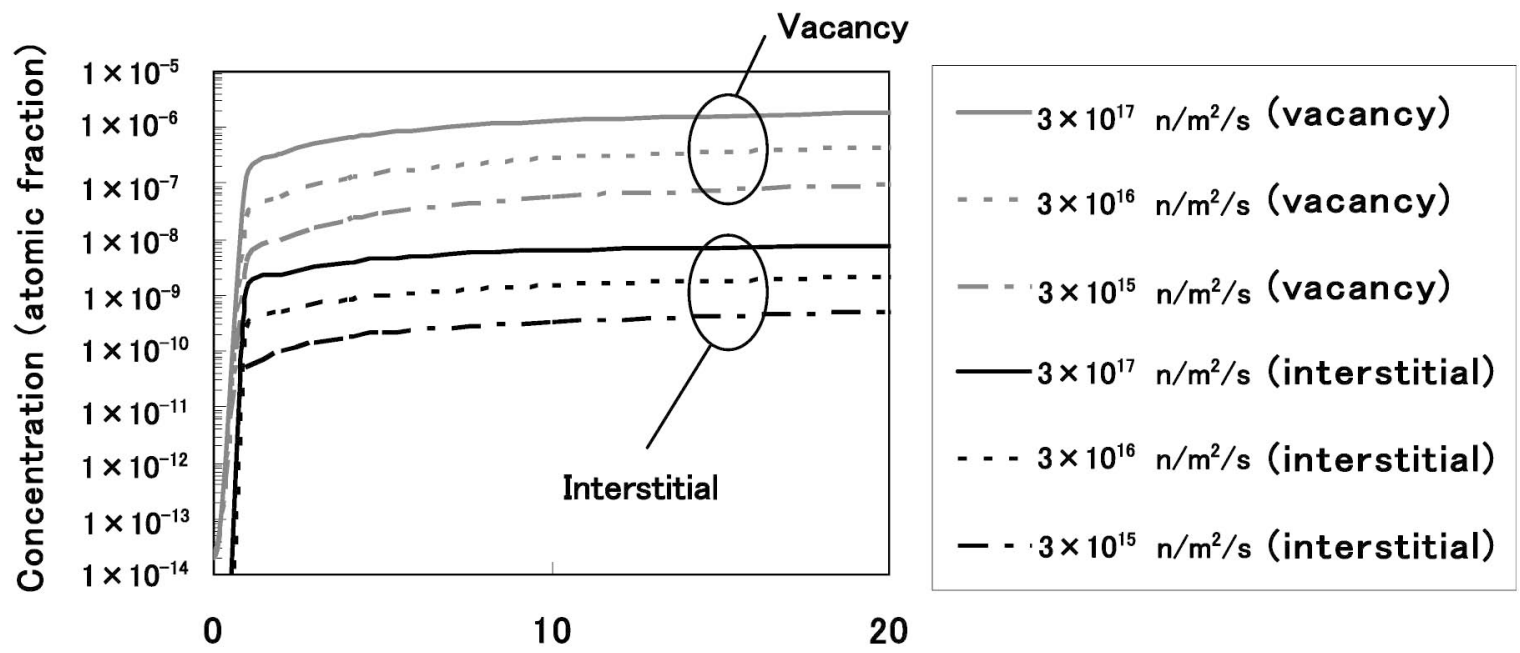

Distance from GB / nm

Fig. 7 Neutron flux dependence of calculated vacancy and interstitial concentrations in type 316 stainless steel. 


\section{(a)}
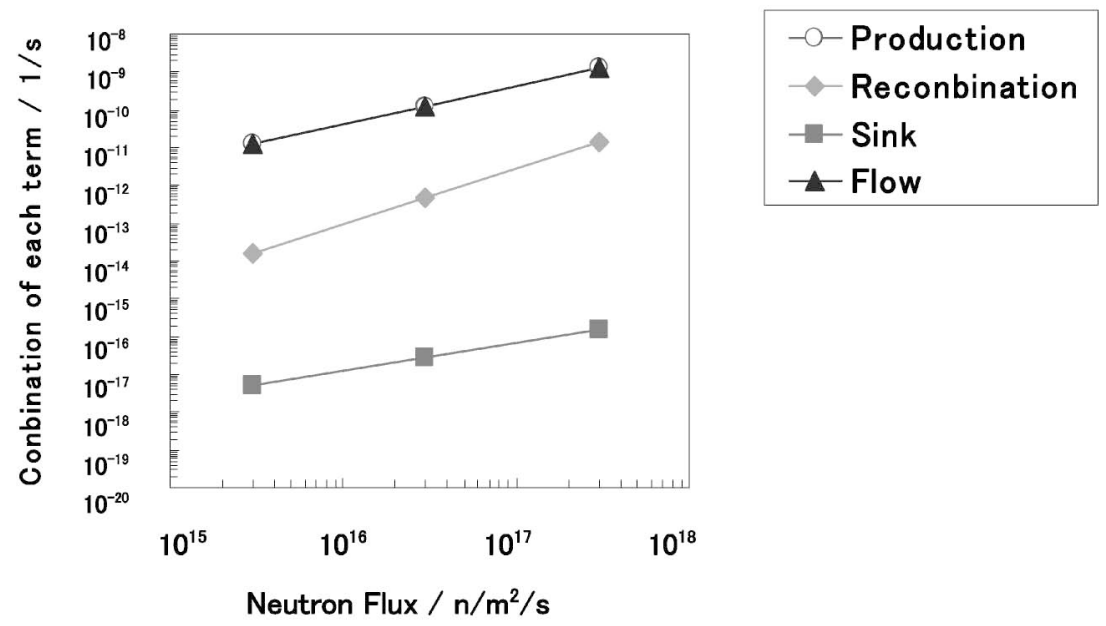

(b)

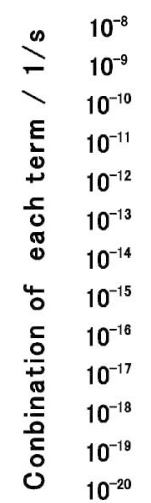
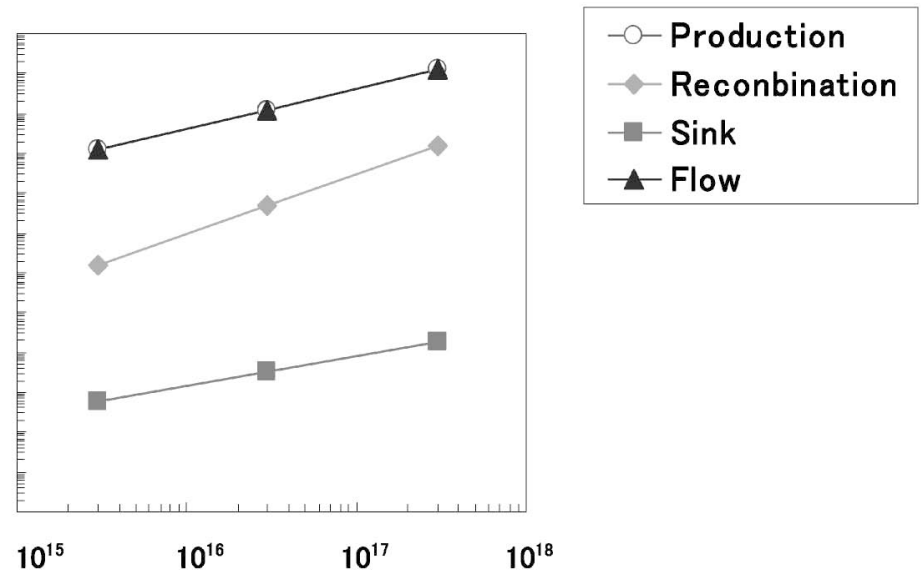

Neutron Flux $/ \mathrm{n} / \mathrm{m}^{2} / \mathrm{s}$

Fig. 8 Calculated results of neutron flux dependence of contribution of each term in type 316 stainless; (a) vacancy, (b) interstitial.

かに存在し，絶対值で $1 / 5$ 程度の依存性を示すことが確認 できた。

今回採用した $\mathrm{Fe}-\mathrm{Cr}-\mathrm{Ni}-\mathrm{Si}-\mathrm{Mo} 5$ 元系モデルならびに最 適化した物理定数を用いて計算した結果は, 実験データで得 られた粒界近傍での $\mathrm{Cr}, \mathrm{Ni}, \mathrm{Mo}$ の濃度変化の幅抢よび深 さ, 粒界に抢ける溶質原子 $\mathrm{Fe}, \mathrm{Cr}, \mathrm{Ni}, \mathrm{Si}, \mathrm{Mo}$ の偏析量をよ く再現しており，BWR 照射 316 ステンレス鋼へ適用できる ことが示された.

\section{4. 結 論}

本研究では, BWR で照射されたステンレス鋼に対する $\mathrm{Fe}-\mathrm{Cr}-\mathrm{Ni}$-Si-Mo 5 元系モデルの適用性を検討することを目 的とし, BWRの照射温度条件 $288^{\circ} \mathrm{C}$ において, 粒界偏析に 対する主要な物理定数の感度解析を実施した. そして報告さ れている BWR 照射 316 ステンレス鋼の粒界偏析測定デー タを再現するように物理定数を最適化した。また，BWR 照 射 316 ステンレス鋼中の粒界偏析に及ぼす照射量, 中性子 束の影響を実験データと解析結果との比較を行った. その結
果，以下の知見が得られた。

(1) 照射誘起偏析に関する拡散定数等の主要な物理定数の うち, 空孔移動エネルギー, Ni と空孔のジャンプ頻度, Ni と格子間原子のジャンプ頻度, $\mathrm{Ni}$ と格子間原子の結合エネ ルギー，Si と格子間原子のジャンプ頻度，Si と格子間原子 の結合エネルギーが粒界偏析に対して影響が大きい。

(2) 最適化を行った物理定数を用いて，BWR 照射 316 久 テンレス鋼の照射誘起偏析を解析したところ, 実験データで 得られた粒界近傍での Cr, Ni, Mo の濃度変化の幅や粒界に おける溶質原子 $\mathrm{Fe}, \mathrm{Cr}, \mathrm{Ni}, \mathrm{Si}, \mathrm{Mo}$ の偏析量をよく再現する ことができた。

（3）最適化したモデルにより低中性子束領域での中性子束 依存性を調べた結果, 粒界偏析は中性子束の約 $1 / 5$ 乗の依 存性を示すことがわかった。

(4) $\mathrm{Fe}-\mathrm{Cr}-\mathrm{Ni}-\mathrm{Mo}-\mathrm{Si} 5$ 元系モデルにより BWR 照射 316 ステンレス鋼の照射誘起偏析の解析が可能である.

本研究を遂行する上で多大なるご協力をいただいた株式会 社原子力システム研究所 福谷耕司博士に謝意を表します. 


\section{文献}

1) P. L. Andresen, F. P. Ford, S. M. Murphy and J. M. Perks: Proc. the 4th International Conference on Environmental Degradation of Materials in Nuclear Power System -Water Reactors, NACE, (1990) pp. 83-121.

2) D. J. Edwards, F. A. Garner, B. A. Oliver and S. M. Bruemmer: Proc. the 10th International Conference on Environmental Degradation of Materials in Nuclear Power System -Water Reactors, NACE, (2002) Paper 62.

3) S. M. Bruemmer, E. P. Simonen, P. M. Scott, P. L. Andresen, G. S. Was and J. L. Nelson: J. Nucl. Mater. 274(1999) 299-314.

4) M. Yamawaki, T. Onchi, K. Fukuya, T. Nakamura, F. Takahashi, T. Tsukada and S. Uchida: J. Nucl. Science and Technology 47 (2005) 385-397.

5) T. R. Allen, J. T. Busby, G. S. Was and E. A. Kenik: J. Nucl. Mater. 255 (1998) 44-58.

6) E. P. Simonen and S. M. Brummer: J. Nucl. Mater. 239(1996) $185-193$.

7) A. M. Yacout, N. Q. Lam and J. F. Stubbins: Nucl. Instrum. Methods in Physics Research B 42(1989) 49-60.

8) S. Watanabe, N. Sakaguchi, N. Hashimoto and H. Takahashi: J. Nucl. Mater. 224 (1995) 158-168.

9) N. Sakaguchi, H. Takahashi and H. Ichinose: Mater. Trans. 46 (2005) 440-444.

10) K. Fukuya and K. Fujii: J. Institute of Nuclear Safety System 14
(2007) $136-155$.

11) T. Torimaru, M. Kodama, S. Tanaka, T. Nakamura, K. Asano and K. Kumagai: J. ASTM International 2(2005) Paper ID JAI12843.

12) K. Nakata, S. Kasahara, H. Takeda and M. Oishi: Proc. the 9th International Conference on Environmental Degradation of Materials in Nuclear Power System -Water Reactors, NACE, (1999) pp. 767-774.

13) Y. Isobe, N. Shigenaka, T. Hashimoto, K. Nakata, M. Kodama, K. Fukuya and K. Asano: J. Nucl. Science and Technology $\mathbf{3 6}$ (1999) 282-287.

14) S. Nakahigashi, M. Kodama, K. Fukuya, S. Nishimura, S. Yamamoto, K. Saito and T. Saito: J. Nucl. Mater. 179-181 (1991) 1061-1064.

15) K. Asano, K. Fukuya, K. Nakata and M. Kodama: Proc. the 5th International Conference on Environmental Degradation of Materials in Nuclear Power System -Water Reactors, NACE, (1991) pp. 838-843.

16) K. Chatani, Y. Kitsunai, M. Kodama, S. Suzuki, Y. Tanaka, S. Ooki, S. Tanaka and T. Nakamura: Proc. the 12th International Conference on Environmental Degradation of Materials in Nuclear Power System -Water Reactors, NACE, (2005) pp. 349-356.

17) R. W. Chan and P. Hasen: Physical Metallurgy, 4th, revised and enhanced edition, volume II, (North-Holland, 1996) p. 1710.

18) F. Kano, K. Fukuya, S. Hamada and Y. Miwa: J. Nucl. Mater. 258-263 (1998) 1713-1717.

19) T. R. Allen, J. I. Cole, E. A. Kenik and G. S. Was: J. Nucl. Mater. 376(2008) 169-173. 